\title{
The Palestine Solidarity Movement, Human Rights and Twitter
}

SHADI ABU-AYYASH, National University of Ireland Galway

\begin{abstract}
This paper examines the reaction of the Palestine Solidarity Movement in Ireland and the UK to the recent Israeli war on Gaza. It studies how the major solidarity groups used Twitter in their endeavour to show online audiences the Palestinian narrative, along with providing information on local solidarity activities. The paper suggests that the Twitter platform was used by major solidarity groups during the war as a tool to connect with Palestinian activists, to inform online followers about human stories of the Palestinian victims and to organise local supporting activities. Results suggest that the text and images used, support the movement's emphasis on human rights discourse.
\end{abstract}

\section{KEYWORDS}

Palestine; Israel; Solidarity Movement; Framing Tasks; Twitter 


\section{Introduction}

Collective action, one of the major elements which contemporary social movements try to create and maintain (Tarrow 1996, 2011; Diani and McAdam 2003; della Porta and Diani 1999), is becoming more cost effective, frequent and wide ranging as a result of the advances in information and communications technologies (ICTs). The growing relationship between contemporary activism and the internet is increasingly studied and is a central concept that this paper addresses in relation to the Palestine Solidarity Movement.

The Israeli military operation against the Gaza strip, south of Palestine, in the summer of 2014, codenamed by the Israeli government as Operation 'Protective Edge', was received with outrage noticeable on social media platforms and on the streets of Ireland, the UK and around the globe. The war, which lasted over a month and left more than 2,000 Palestinians dead and another 11,000 injured, ${ }^{1}$ was unique on two levels: the impressive military resistance of the Palestinian factions and the massive demonstrations around the world that showed global solidarity with the people of Palestine and particularly with the citizens of the Gaza strip.

While Western mainstream media in Europe and the US have been accused by the Palestinians and their supporters of being biased in favour of the Israeli narrative of the war, internet-mediated platforms including social media sites have been widely used by proPalestinian activists around the globe to counter this bias and to provide the internet audience with the Palestinian side of the story.

This paper looks at the methods used by pro-Palestinian groups in Ireland and the UK combining online and offline means of mobilising protests in major cities in the country. It addresses two questions: how Twitter was utilised by the Ireland and UK solidarity groups during the Israeli offensive in Gaza; and what kind of discourse was communicated on Twitter during this particular period.

Applying a framing analysis approach, the article draws attention to the role that social media sites, Twitter in particular, play a role in informing online communities and solidarity movements, their members, associates and online followers, about a global cause, such as the Palestinian cause. It also examines the human rights discourse adopted by the solidarity movement and possible reasons behind this adoption.

The main argument in this paper is that internet-mediated platforms such as Twitter serve as a valuable tool to inform and organise, a notion that has been addressed by many scholars in light of the Arab Spring and Occupy Wall Street Movement (Castells 2012; Bennett and Segerberg 2012).

\section{ICTs and New Social Movements}

Communication is often considered a key factor in the deveelopment and advancement of social movements. As Melucci (1995) argues, communication has had an impact on the focus

\footnotetext{
${ }^{1}$ Palestinian Ministry of Health, “Emergency Operation Room Sitrep on Gaza, August 31 ${ }^{\text {st". }}$ (2014). http://www.moh.ps/attach/761.pdf (accessed 16/09/2014).
} 
of social movements making it become much more cultural. For social movements activists, the highly interactive medium of the internet has given them a place to assemble and to exchange information and experiences.

The internet has also added value to activists' endeavours to deliver their message to their audience. Holmes says that 'compared to broadcast forms of media, the internet is said to offer free-ranging possibilities of political expression and rights of electronic assembly which encounter far fewer constraints, whether technical, political or social' $(2005,9)$. For Castells (2012), the major change is the way in which communications can now be mass communications or can be tailored to individuals.

The development of ICTs is also a successful solution to the high cost of transactions between transnational social movements, as well as locals collaborating and networking. Shirky highlights the significance of 'social tools' for collective action and group collaboration:

The cost of all kinds of group activity-sharing, cooperation, and collective action have fallen so far so fast that activities previously hidden beneath that floor are now coming to light, we didn't notice how many things were under the floor because, prior to the current era, the alternative to institutional action was usually no action. Social tools provide a third alternative: action by loosely structured groups, operating without managerial direction and outside the profit motive. $(2008,47)$

Tarrow (2011) also sees the impact of the internet and ICTs as the most dramatic change in the organisation of social movements. He argues that the internet has become a tool for organisers, a message transmitting vehicle. The advancement of communication technologies has also had an impact on methods of assembling. New media has facilitated communication and gathering for activists, friends, colleagues and family members. Castells (2005) suggests that society shapes technology based on its needs and not the other way round.

In the context of social and political movements, another argument for the importance of the two way mode of communication in political struggles is that this kind of global communication allows activists to monitor and learn from the experiences of others and set ethical rules for these actions (Lipschutz 2005).

In their recent work, Trottier and Fuchs (2015) provide a broader argument in which they consider social media as an arena for the demonstration of contradictory powers. They argue that social movements that rely on knowledge and communication use alternative media as a necessity to overcome their limited access to the traditional state-run and corporate media that negatively frame social movements.

Similarly, Bennett and Segerberg argue that calls for action that reach audiences on these technological platforms show how actions can be organised. They state that activists are aware that social media reduces the cost of organising and reaching out to other activists and audiences, although they do not replace the traditional forms of action.

Digital media networking can change the organizational game, given the right interplay of technology, personal action frames, and, when organizations get in the game, their willingness to relax collective identification requirements in favor of personalized social networking among followers. $(2012,748)$ 


\section{Pro-Palestine Activism}

The advance of the internet, which led to the creation of many mediated websites and forums about the Palestinians, has helped in creating an opportunity for Palestinians to reach an international audience and therefore tell their version of the story (Stamatopoulou-Robbins 2005).

In her examination of the effects of the internet on the construction of Palestinian virtual communities, Aouragh notes that 'immobility and control was partly overcome when internet usage enabled direct transnational communication and grassroots participation in news production'(2008, 254). Dudouet (2006) shows how communication is a vital aspect of the pro-Palestine International Solidarity Movement's (ISM) work, and Seitz (2003) suggests that the internet was widely used by prospective volunteers who could log on to the ISM website to find information and get involved in volunteering programmes in Palestine.

In the US context, Marmura argues that although the pro-Palestine camp in the US is less well resourced and less influential than the Zionist organisations, the internet provides added value to their activism (2008).

As for the Palestine Solidarity Movement activists in the British context, the use of social media platforms has always been part of the movement's communication strategy and the recent war on Gaza was no exception. Kajsa Anckarstrom of the Manchester Palestine Solidarity Campaign explains that using internet-mediated platforms, mainly social media sites, is popular among pro-Palestine activists for many reasons, including keeping in contact with the people of Palestine and raising awareness about life in Palestine under the Israeli military occupation among online audiences.

On many online campaigns we have many Palestinians leading the way; be it petitions, hashtag campaigns, raising funds for projects, Palestine Solidarity Campaign liaises with Palestinians in Gaza and the West Bank in regards to projects and inviting Palestinians over for talks which are open to the public to increase awareness (written communication 5 December 2013).

\section{Palestine Solidarity Movement in Ireland and the UK}

Although the Palestine Solidarity Movement is a transnational social movement in its form and a transitional advocacy network in its character and mission, in practical terms it adopts and implements the activism methods of the new social movements.

Pro-Palestine groups in the Republic of Ireland and the UK have different levels of online and offline activity. They also have different areas of focus and specialisation. The leading groups that work at the national level can be classified as belonging to the active working networks that are operating in the two countries. In Britain, these are the Palestine Solidarity Campaign UK (PSC) with its local affiliated groups in many cities in England and in Cardiff in Wales; the Scottish Palestine Solidarity Campaign (SPSC) with its local branches all over Scotland; and the students' network, which is made up of all Palestine societies that are active in English and Scottish universities. Meanwhile, Ireland Palestine Solidarity Campaign (IPSC) is the most active and widespread group in the Republic of Ireland, as it has branches in almost every Irish city. That said, the Derry-based group, Irish Friends of Palestine, is the 
most active solidarity group in Northern Ireland. These groups will form the case studies and focus of this paper's analysis.

\section{Areas of Activism}

Through three years of observing the work of the main solidarity groups in the two countries, the author distinguished the main areas of activism that are the core of their work. The groups carry out activities on two levels (see diagram 1): regular ongoing campaigns and responsive campaigns.

Regular ongoing campaigns are focused on two areas: first, advocating the Boycott, Divestments and Sanctions against Israel (BDS) call; and, second, raising awareness of the Palestine cause through online and on the ground activities. On BDS, activities include encouraging shoppers to boycott products from Israeli settlements, supporting BDS motions at campuses and unions, regularly sharing news on social media platforms about BDS success stories, and lobbying actors, bands and singers to adopt the call and cease performing in Israel.

The activities aimed at raising awareness of the Palestine cause include providing online audiences on social media sites and group websites with stories of a human rights nature. Such stories include information about the living conditions of the Palestinian people under the Israeli military rule of the occupied Palestinian land. Other regular activities consist of arranging public talks in their local areas and lobbying British and Irish parliament members in relation to Palestine to a regular pattern.

Responding to major events in Palestine such as the recent Israeli war on Gaza, or the hunger strike by Palestinian political prisoners in Israeli jails, solidarity groups similarly take on line and on the ground actions. Activity on social media sites such as updating followers on news from Palestine noticeably increases during crises. On the ground activities would include arranging demonstrations and protests with local allies such as unions, issuing press releases that condemn the Israeli actions against the Palestinians, and contacting local parliamentary members and decision makers in the UK and republic of Ireland. 


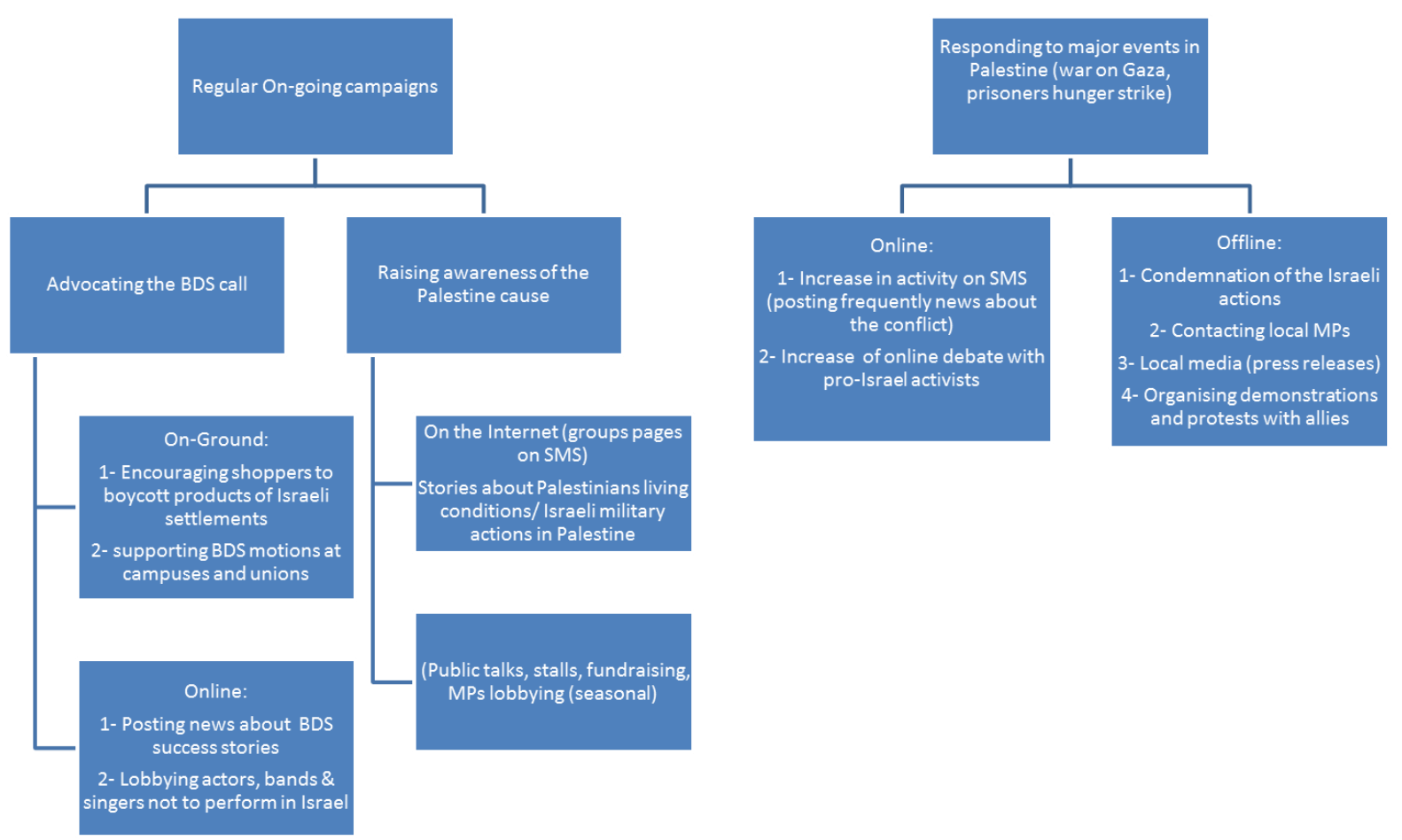

Diagram 1: Solidarity groups on-line and offline regular and responsive activities.

\section{Methodology}

This article is taken from the author's current doctoral research which takes a number of events related to the Palestinian conflict and looks at the high level of activity from solidarity groups on social media platforms and webpages in response to the Israeli narrative during the war. It also examines on the ground activities that took place around the world, including Ireland and Britian. It does so through online content analysis, interviews with activists and author observation to provide a considerable amount of data for analysis.

In particular, the research used twenty Twitter accounts of the major solidarity groups in Ireland and the UK as a case study. For Yin, using a case study is a favoured method for examining research questions which explore how and why. He states that "case studies are the preferred strategy when "how" or "why" questions are being posed, when the investigator has little control over events, and when the focus is on a contemporary phenomenon within some real-life context' $(2003,1)$. In addition, it has been argued that case studies give a deeper grasp of particular instances (Mabry 2008).

These groups represent an ideal transnational advocacy network that adopts the contemporary tactics of online activism, including the use of internet-mediated platforms for communicating and organising.

\section{Collected Data}

The unit of analysis was the Twitter accounts of the selected groups. The time frame of the war, which lasted from 8 July to 26 August 2014, was divided into weeks, and content was 
collected from three weeks: the first week (from 8 to 15 July), the fourth week (29 July to 3 August) and the last week (20 to 26 August). All content was coded, classified and analysed. In other words, the author analysed all published content in the 20 Twitter accounts from the first, the middle and the last weeks of the war. A total of 105 tweets were coded and analysed by theme.

\section{Framing Processes Approach}

The Twitter accounts' content was analysed through the theory of the framing processes of social movements. To do this, the analysis identified the three framing tasks: diagnostic, prognostic and motivational. That is, it was important to understand how the solidarity group activists framed the war on Gaza in terms of how they understood it (diagnostic), their suggested actions to counteract it (prognostic) and their efforts to initiate action through the wider participation of other local social and political movements (motivational).

Cress and Snow argue that, for social movements, 'the diagnostic and prognostic framing tasks, play an important but unrecognized role in the attainment of desired outcomes' (2000, 1071). They explain that diagnostic framing is essential as it addresses how problems are perceived and the sources of problems, while prognostic framing suggests solutions and goals to be achieved by the movement. Motivational framing arguably calls supporters to collective action and includes creating a language that motivates participants. It is "a "call to arms" or rationale for engaging in ameliorative collective action, including the construction of appropriate vocabularies of motive' (Benford and Snow 2000, 617).

Lee explains that 'through framing processes activists deconstruct the language disseminated by mainstream institutions and articulate a new language and narrative of their own that clarify their agenda.' $(2009,57)$.

\section{Results}

\section{War News}

Results show that most of the Twitter content was dedicated to sharing information about the war in Gaza, mainly news updates and stories of the victims of the Israeli military operation. As shown in graph 1, 75 per cent of the content analysed refrenced war news, 9 per cent focused on information about the groups' activities on the ground, mostly street demonstrations, and 9 per cent was content related to its online activities, mostly calling followers to sign online petitions. 


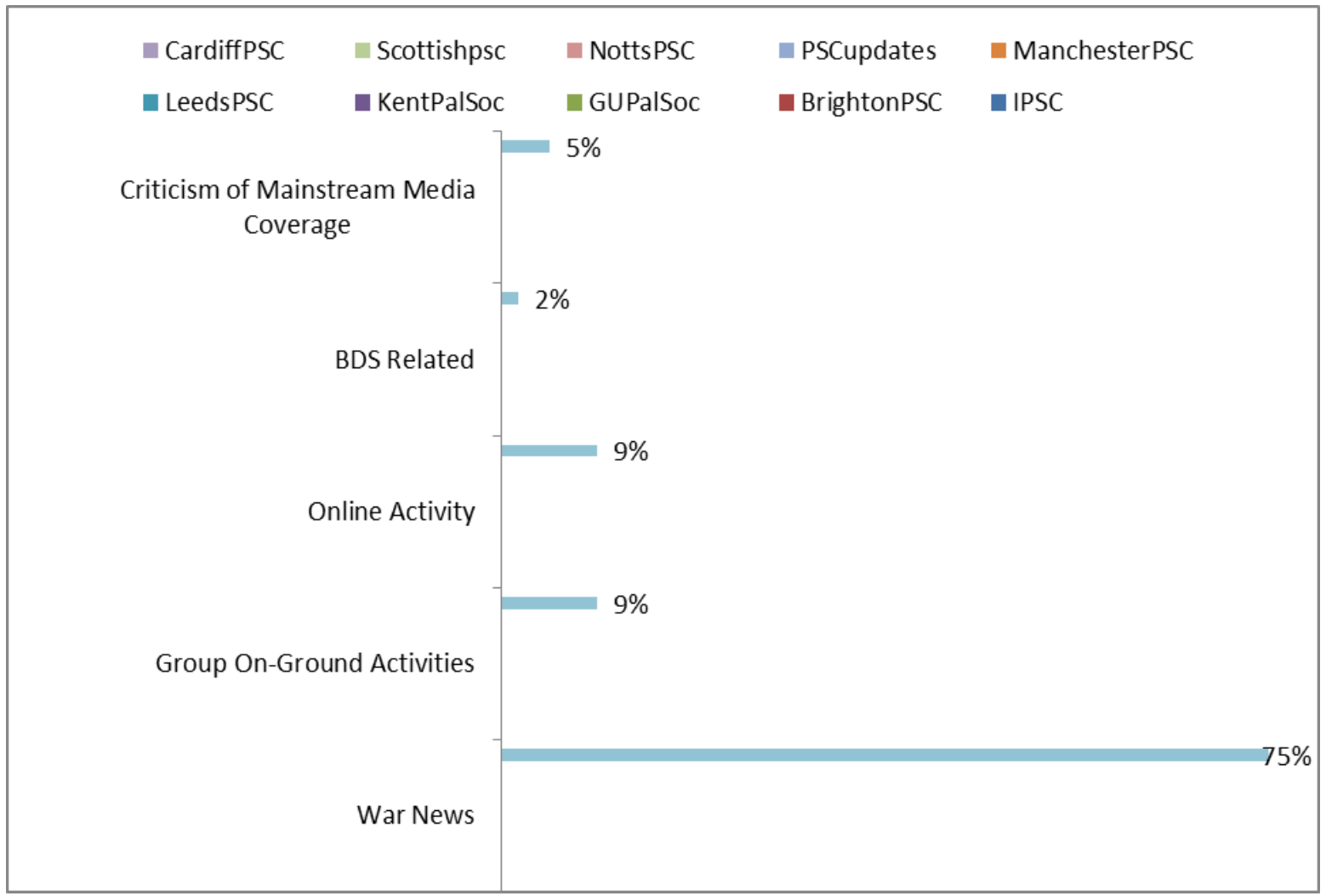

Graph 1: Themes of solidarity groups' Twitter accounts feed

Given the situation in Palestine is the focal point for the examined solidarity groups, it is logical that most of the content published online by these groups touch on the developments of the war in Gaza. Hourly news updates detailing the situation in Gaza during the Israeli military operation topped the content of solidarity groups' Twitter content.

Updating Twitter followers on news of Gaza victims complied with the aim of using social media sites to inform. The constant sharing and tweeting of news, including images from Gaza, with a focus on the increasing number of casualties among Palestinian civilians, Israeli airstrikes and the destruction of civilian areas in Gaza, served two main purposes. First, supplying Twitter followers with much more detailed stories about daily events in Gaza, in a pro-Palestinian frame which focused on humanising the Palestinian victims, mainly children and women. These frames also contradicted the Western mainstream media narratives that portrayed the war as an armed conflict between two militarily equal sides. Second, this would encourage activists and followers to participate in organised demonstrations at local and national levels in Irish and British cities.

Furthermore, focusing on civilian casualty stories, by providing images and touching stories of Palestinian children fighting for their lives along with their families as a result of Israeli missiles, would also reinforce the human rights aspect of the conflict that the solidarity movement discourse is focused on. As graph 2 below indicates, around 38 per cent of war news content is about casualties and death toll numbers rather than about political positions or the Palestinian resistance during the war.

The high number of civilian victims and the considerable destruction of Gaza by Israeli airstrikes forced the solidarity movement in the UK and Ireland to focus its online content on disseminating events related to the development of the war on the ground. This was in 
contrast to the Palestinian activists in Palestine who widely celebrated the improved performance of the resistance in Gaza throughout their activity on social media sites during the war.

Along with news stories, critical opinions of the Israeli military operation against the Palestinians in the Gaza Strip were also widely disseminated on solidarity groups' Twitter accounts. Opinions made up around 21 per cent of the content, as graph 2 shows, and came in the form of articles, interviews and commentary written and delivered by renowned global politicians, analysts, journalists and even celebrities.

Sharing analysis reports that criticised the Israeli military operation served three purposes. First, it provided additional and deeper understanding of the political motivations behind the Israeli operation, which would be an added encouragement for activist and online followers to challenge Israeli policies through participation in solidarity activities. Second, it showed Palestinians and their supporting activists in the West that that they were not alone in their struggle against the Israeli occupation policies in the occupied Palestinian land. Third, these comments would help the solidarity movement's constant framing of the conflict as being between Israel, the military occupying power, and the oppressed unarmed Palestinian people.

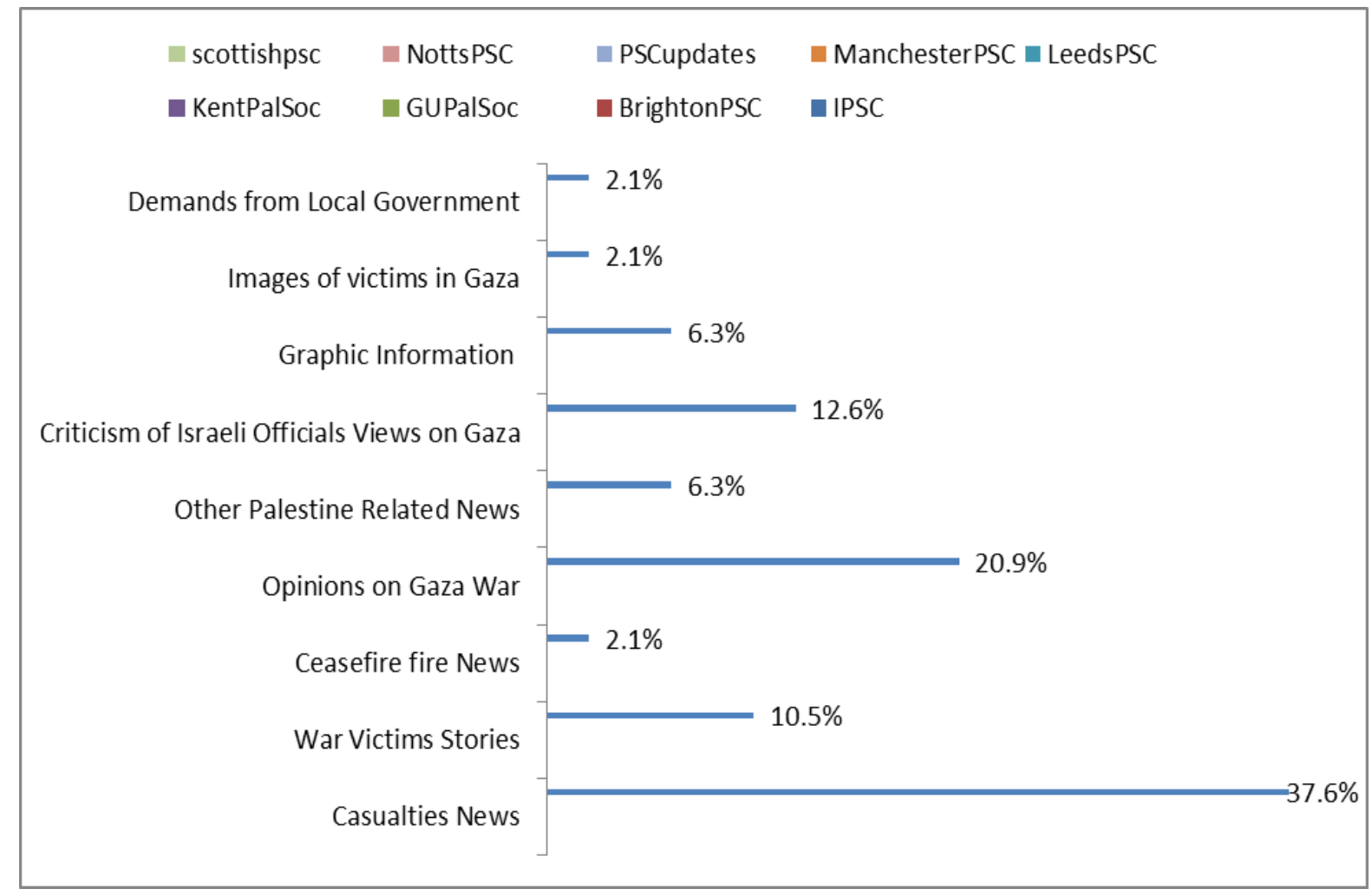

Graph 2: Classification of content posted on solidarity groups' Twitter accounts during the war

\section{News Sources}

News sources used to infrom the solidarity groups' tweets did not come from mainstream media, but rather from Palestinian or pro-Palestinan publications. The groups' Twitter accounts during the war provided constant updates on the number of Palestinian victims of the Israeli military operation, including the numbers of deaths, injuries and destruction of properties in Gaza. 
The Twitter accounts of Ireland and UK-based solidarity groups used news stories from friendly pro-Palestine sources and from social media accounts of other Palestinian-based activists. Results, shown in graph 3 below, indicate that 35 per cent of the news that appeared in the analysed tweets came from the Palestine-based English news site Maan News Agency and the US-based pro-Palestine news agency, Electronic Intifada. Some 65 per cent of the tweeted news came from other renowned news sources such as the Guardian, the Independent, the Journal.ie, Aljazeera's English service and Channel 4 News, mainly from the Twitter account feeds of its journalists Jon Snow and Jonathan Miller.

Most of the Maan News Agency and Electronic Intifada stories framed the events of the war in a similar manner, presenting the Israeli occupation as the problem and Israeli aggressive military policies as the cause of the current escalation.

Informing local audiences about the Palestinian-Israeli conflict using alternative media sources not only increases awareness about the nature of the conflict, but also challenges the Western mainstream media frames of the conflict. It can also be seen as an attempt to advance the Palestinian narrative and make it accessible to the Western public.

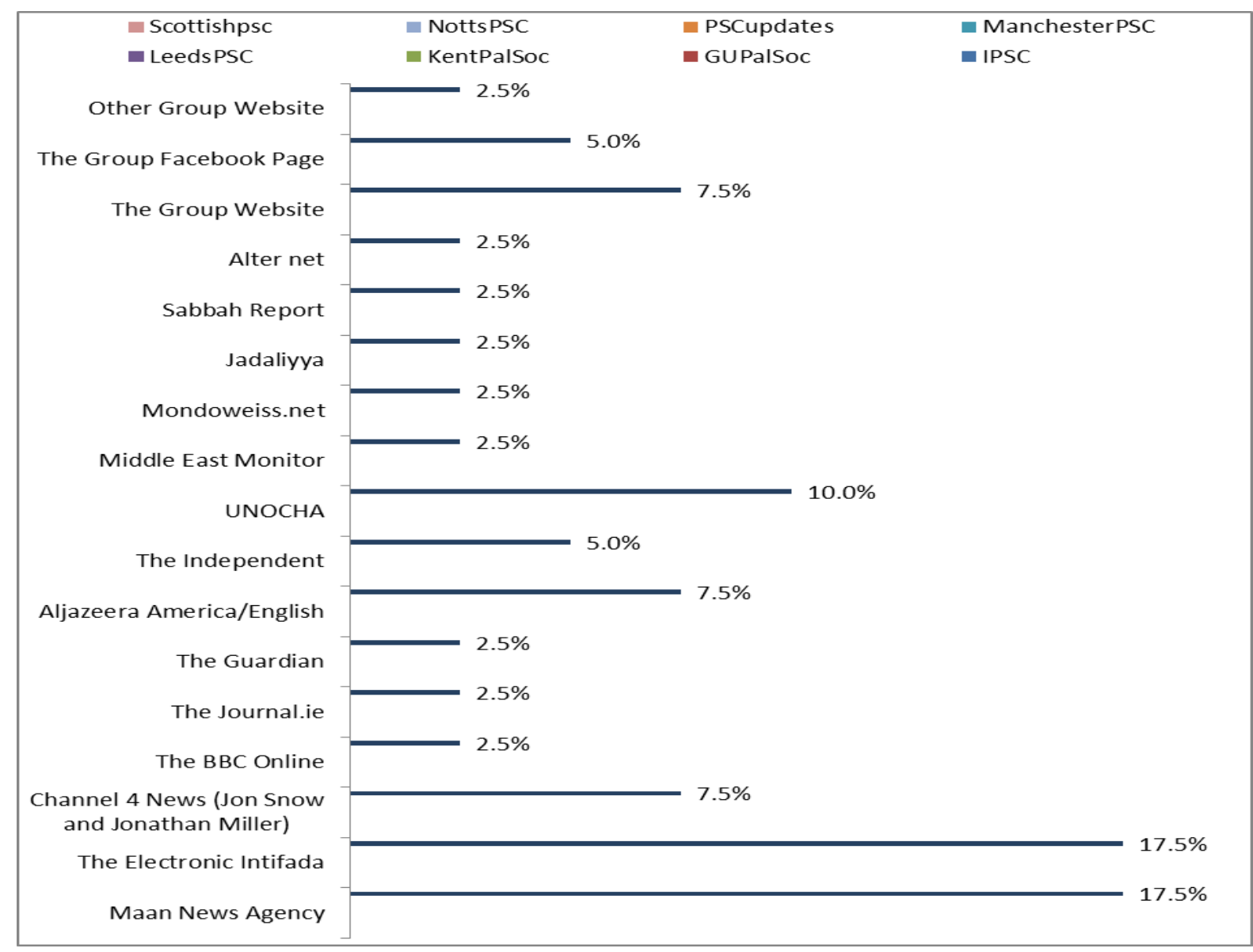

Graph 3: sources of the news about Gaza that solidarity groups tweeted on their Twitter accounts during the war

\section{Popular Hashtags}

The hashtags used on Twitter by solidarity groups in the UK during the war on Gaza varied to some extent (see graph 4), with \#Gaza and \#GazaUnderAttack being the most popular 
given most of the tweets' addressed the daily happenings of the Israeli offensive in Gaza. Such hashtags were often accompanied with text and images of the war.

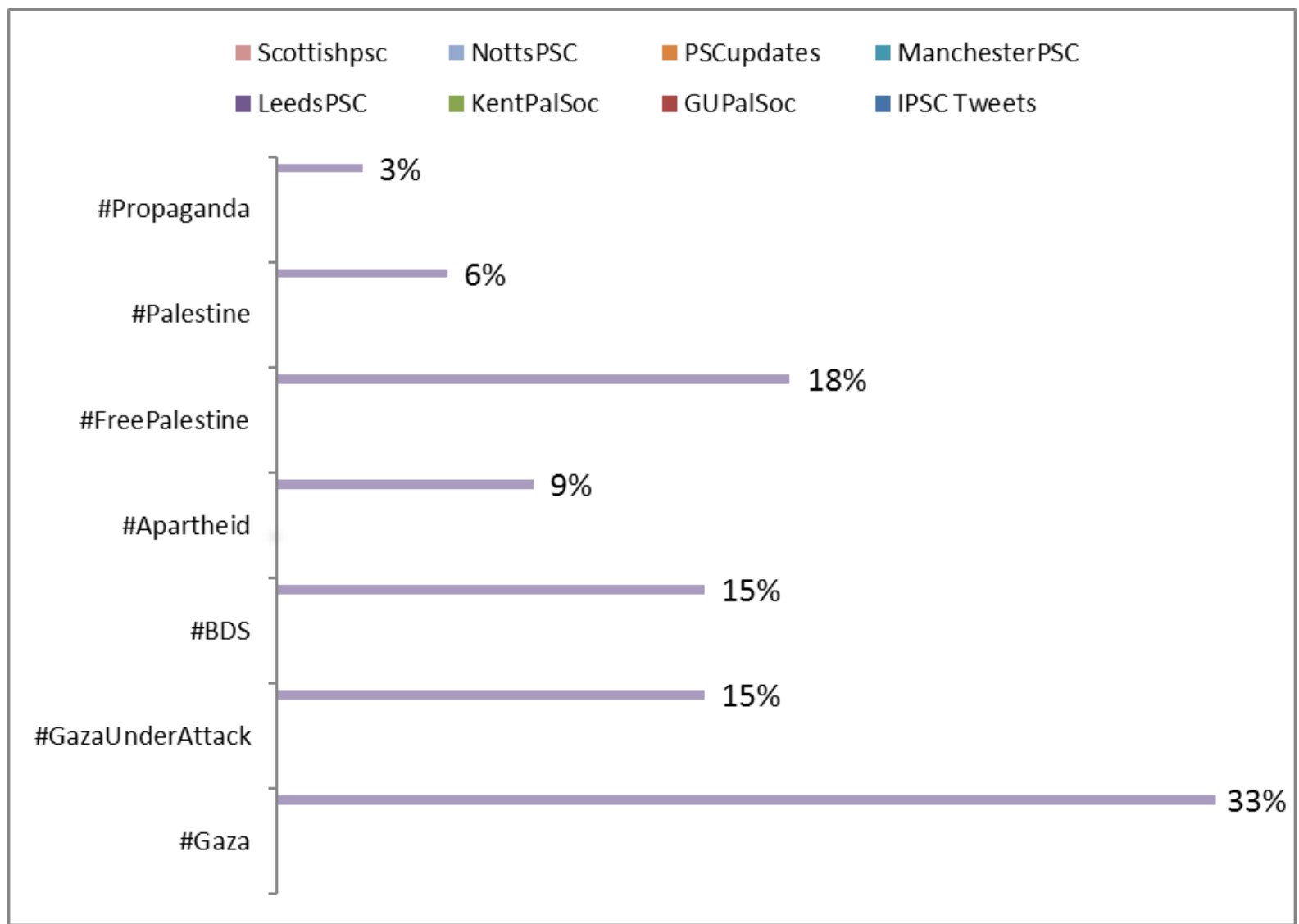

Graph 4: Twitter hashtags that solidarity groups used during the war on Gaza

\section{Groups on-Ground Activities}

During the war, social media activity by solidarity groups increased exponentially, providing information on demonstrations, vigils and protests seen daily. Every local, national or university-based solidarity group in Ireland and the UK organised demonstrations in solidarity with Gaza during the war, in coalition with local and national social movements, organisations such as unions and anti-war movements.

Many of the studied solidarity groups who were active on Twitter during the timeframe of the analysis provided information on their local solidarity activities - prior the protests, during, and after it had happened. Results indicate that the majority of the tweets in relation to group activities were calling for participation in these activities.

Along with asking the Twitter audience to participate in the 9 August 2014 demonstration that took place in central London, at which the Stop the War coalition estimated the number of participants at around 15,000 persons, ${ }^{2}$ activists initiated a special hashtag (\#GazaA9) for this demonstration that proved to be very popular on Twitter. The demonstration was not only

\footnotetext{
${ }^{2}$ Stop The War coalition, '9 August 2014: The biggest ever UK demonstration for Gaza', http://stopwar.org.uk/resources/reports/9-august-2014-the-biggest-ever-uk-demonstration-for-gaza, (accessed 12 October 2014)
} 
a success story in relation to using social media for on the ground activity, but also an example of how British-based solidarity groups organise activities with their local allies such as unions and anti-war movements.

The use of Twitter hashtags for particular organised events show that social media sites are not only used for informing followers/online communities about international causes, but also for organising and reaching as many local participants in an easy, efficient, and low cost manner. Using a particular hashtag for a particular event also unites the online efforts of all parties involved in organising a national grassroots activity. Such methods facilitate access to information, including updates and images about the particular activity both in the preparation phase and while it is actually taking place.

\section{Framing Tasks: Diagnostic Frame}

The language used to describe the Israeli military offensive in Gaza fell into two main categories: critical descriptive language about the Israeli behaviour, which can be further divided into political, legal and human rights discourses; and propositional language that proposes actions to counteract this adverse behaviour.

As table 1 indicates, most of the phrases used on Twitter accounts from the groups are critical of the Israeli military offensive in Gaza; words and phrases that focus on the Israeli violation of human rights and international law are very noticeable in the solidarity movement's discourse on the internet.

Political phrases such as 'coloniser', 'occupation' and 'invasion' are used to describe the nature of Israel as an occupying power, while violations of human rights and international law are widely used to frame the Israeli actions against the Palestinians. Terms like 'apartheid', 'outlaw state', 'ethnic cleansing', 'war crimes' and 'humanitarian crisis' are popular descriptive terms of Israeli actions. That is to say that solidarity groups frame Israel as a colonising occupying power and as a violator of human rights, while the solidarity movement activists sees themselves as human rights defenders whose focus is on showing solidarity and support to the people of Palestine in their struggle against the foreign occupier of their lands.

The movements often defined the problem using the diagnostic frame. The solidarity movements consider the Israeli occupation of the West Bank, Jerusalem, and the control of the Gaza Strip as the main reason for the long-lasting Palestinian-Israeli conflict. They assert that such struggle inspired the creation of the movements in the hope of confronting the occupation and joining the Palestinian people's struggle against it.

\section{Framing Tasks: Prognostic Frame}

Calls for adopting BDS are rising among mainstream solidarity groups globally, including UK- and Ireland-based groups. BDS is seen by the solidarity movement as an effective response to Israel and as a practical measure through which pro-Palestinian activists around the globe can contribute to the Palestinian struggle for independence. 


$\begin{array}{llll}\text { Political Language } & \text { Legal Language } & \text { Human Rights Violations } & \text { What Can Be Done } \\ \text { Coloniser } & \text { Int. Humanitarian Law } & \text { Civilians } & \text { Boycott } \\ \text { Invasion } & \text { Apartheid State } & \text { Humanitarian crisis } & \text { Solidarity } \\ \text { Zionism } & \text { Outlaw State } & \text { Violent Attack } & \\ \text { Occupation } & \text { Ethnic Cleansing } & \text { Onslaught } & \\ \text { Resistance } & \text { Collective Punishment } & \text { Brutality } & \\ & & \text { Racism } & \\ & & \text { War crimes } & \\ & & \text { Oppressor } & \\ & & \text { Slaughter } & \\ & & \text { Death Machine }\end{array}$

Table 1: Classification of phrases used by activists on Twitter to describe Israel's behaviour during the war.

Pro-Palestine activists see the BDS as a useful measure to pressurise Israel to end the occupation of the Palestinian land and comply with international laws, as well as a method that can be applied by the public, without having to wait for official political governmental actions. Raymond Deane, a Dublin-based artist and activist who is affiliated to the IPSC has stressed the importance of showing 'the complicity of our own politicians in perpetuating the Israeli occupation and the Importance of BDS' (Written communication 2 March 2014).

As for relations with local civil societies, mainly with the unions in the Irish context, Kevin Squires, the national coordinator of the IPSC, explained how such relations changed after the war on Gaza. He stated:

During Operation Protective Edge several unions took strong stances against the attack, and in particular Mandate (the retail workers union) began an online petition calling on all Irish retailers to stop stocking Israeli products, while the Communications Workers' Union issued a pamphlet called "The Case for Palestine" to all its members which recommended support for the BDS movement. The ICTU is about to move forward with its consumer boycott campaign. Speakers from ICTU, Mandate, SIPTU and Unite addressed crowds at the IPSC-organised demonstrations in Dublin during the Protective Edge operation. (Personal communication, 28 October 2014)

Although news and descriptions of Israeli actions against Palestinians occupy the majority of the solidarity movement online content, chart 1 shows that the proposed responses to such acts by activists occupy as much as a quarter. BDS, along with other forms of regular solidarity activities, are the main proposed responses to Israeli policies. As the situation on the ground escalated, solidarity groups' twitter feeds where shown to advocate BDS as a necessary 
response. The BDS is therefore the current prognostic frame through which the movement aims at expanding nationally on all levels.

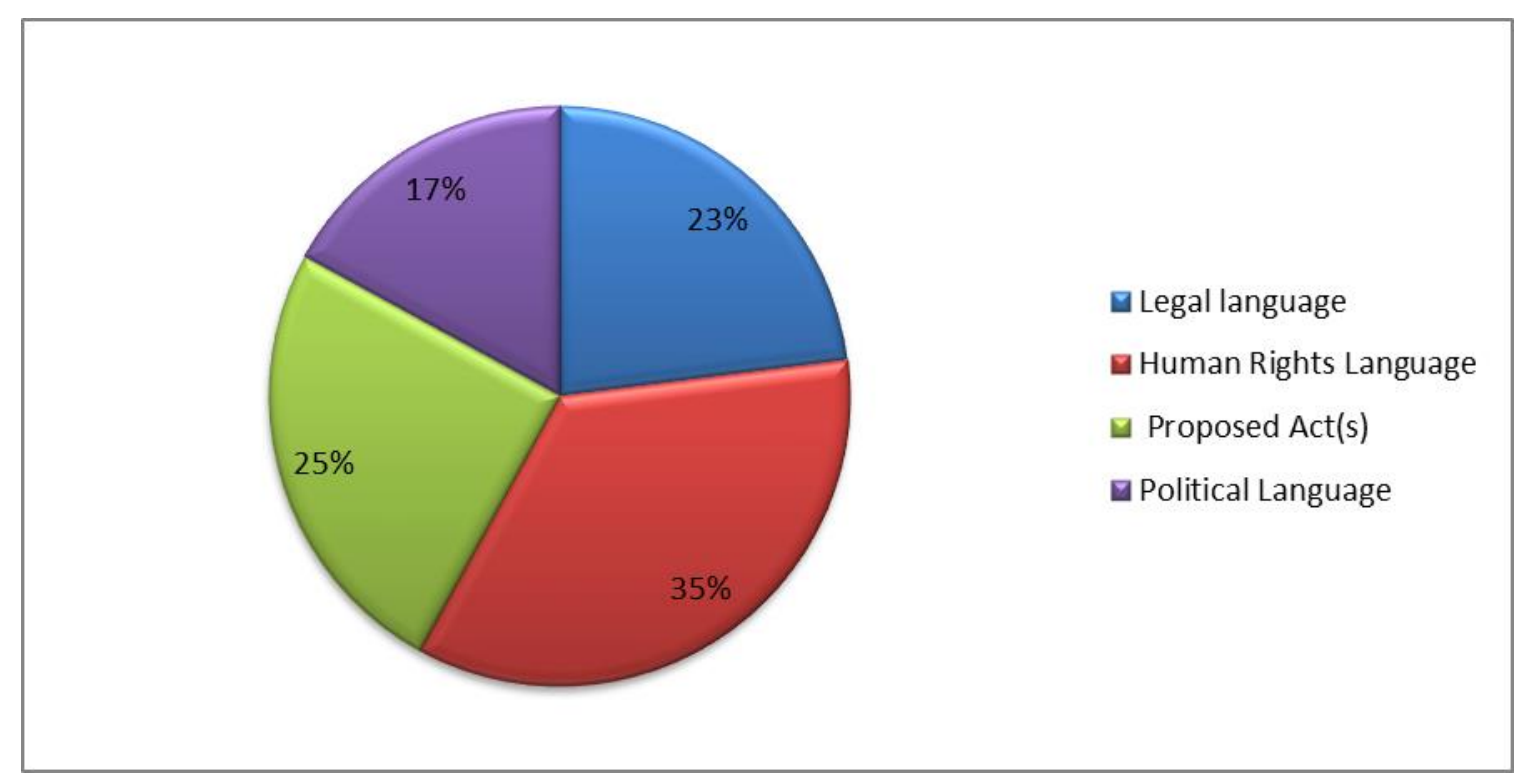

Chart 1: Human rights language, political and legal terms make up 75 per cent of the solidarity movement's online discourse, while proposed solidarity actions such as BDS make up 25 per cent of the content.

\section{Framing Tasks: Motivational Frame and Human Rights Discourse}

Terms used in framing the conflict in general, including daily stories during the war, suggest that solidarity activists adhere to human rights discourse.

Although most of the content from the sampled Twitter accounts during the selected periods was dedicated to informing followers about the situation in Gaza, a great deal of content was also aimed at informing followers about Israeli violations of human rights and asking them to join solidarity events. The massive demonstration which took place in London on 9 August 2014, for example, was a clear example of motivational framing, with solidarity groups asking followers and supporters to participate in organised activities, in collaboration with other local grassroots movements, on the basis of the human rights cause.

The adoption of a human rights discourse, rather than a religious or ethnically driven discourse, serves two purposes. First, by adopting a language that criticises Israeli policies as violating the Palestinian people's human rights, the solidarity movement would be able to draw more attention to this cause in the Irish and British context since the human rights element receives more attention from the public.

Second, defending the human rights of the Palestinian people is an acceptable motive for activists' involvement in the solidarity campaigns. Landy suggests that 'in view of the ubiquity of human rights arguments by the wider Palestine Solidarity Movement, and similar forces operating on this movement (the need to speak to the public in an "acceptable language", to frame movement enemies, to justify one's own involvement, etc.) it appears that a similar process of construction and contention may obtain for these activists as well' $(2013,424)$. 
In this regard, solidarity movement groups share the same mission in supporting Palestinian human rights and defending their right of independence. 'Freedom, justice and human rights for Palestine: activism is a way to achieve that by applying pressure on our governments and advocating the right message' is the main goal of solidarity groups, as the Manchester based pro-Palestine activist Kajsa emphasises in a written communication (5 December 2013).

Framing the conflict only as a human rights matter, without clearly focusing on the political rights of the Palestinian people, including the right of resisting the Israeli occupation, may have adverse implications on the understanding of the conflict by the foreign public. Nevertheless, focusing on framing the conflict through the human rights issue is important for alliance building purposes.

Since it has always been vital for the solidarity movement leaders to engage in collaboration with local social and political actors to build a supportive front for the Palestinian cause in the UK and Ireland, having a widely appealing discourse such as the human rights discourse would encourage those actors, such as unions, anti-war movement etc. to join the efforts of the solidarity movement and adopt their strategies, including supporting the BDS call.

Based on this, it is reasonable to suggest that the solidarity movement's strategy of adopting a human rights discourse as a main pillar would serve alliance building purposes well, and that adhering to a human rights discourse should be seen as a motivational frame for the movement's activists and supporters, as well as for other local allies.

\section{Discussion}

This paper has examined the contemporary concept of internet activism through an analysis of social media content. The study examined the Palestine Solidarity Movement groups' use of Twitter, in the UK and Ireland, during the Israeli war on Gaza in the summer of 2014 as a case study.

Main results suggest that Twitter was widely used for connecting, informing and organising purposes. The content analysis, which applied a framing analysis approach, reaffirmed that the solidarity movement's use of text and images adheres to the movement's human rights discourse, which frames the Israeli policies as violations of Palestinian human rights and sees the BDS as an effective response.

Pro-Palestine activists access information about the situation in Palestine through several sources, including Palestinian online activists via social media sites such as Twitter. Connectivity with Palestinian activists in Palestine enables Irish and British activists to consume news other than that of the mainstream media that frame the Palestinian-Israeli conflict out of its historical context.

News about Gaza from Palestinian sources provided an alternative narrative to the Israeli one, which were circulated by solidarity activists on Twitter for information purposes. Challenging the Israeli narrative and the mainstream media frames is facilitated by social media sites. Such narratives enables pro-Palestinian activists to provide solidarity activists with Palestinian stories that they can expose to Twitter users globally. 
The analysis of online content has been examined through framing - diagnostic, prognostic and motivational. Analysed content suggests that the solidarity groups' diagnostic framing of the Israeli offensive in Gaza sees it as a violation of human rights and international laws. This supports the movement's strategy of focusing on exposing Israeli policies of abusing the Palestinian people's human rights.

The BDS is seen as the heart of the prognostic frame, as solidarity activists believe expanding it is a responsive and effective strategy that should be followed. The analysis suggests that, in crisis, solidarity activists increase their calls for both a long-term strategy to counter Israeli actions through the BDS and short-term action in the form of demonstrations as a direct response to Israeli military action in Palestine.

Motivated by the need to protest against the Israeli offensive in particular and the occupation in general, solidarity movement activists were provided with the political opportunity through the attack on Gaza to organise activities in coordination with their allies and increase the level of collective actions on the ground.

Although this article provides an examination of the online content from the Palestine Solidarity Movement during a time of crisis and has explored the movement's framing tasks, further studies during other periods would be needed to identify a pattern of frames and discourse used online.

As Tarrow (1996) emphasises, political opportunities encourage actors to transform possible mobilisations into actions. The Israeli offensive led to a great number of on the ground activities, mainly protests and vigils, in Ireland and the UK, along with constant publication of content on social media sites including Twitter.

Finally, Twitter is also used for organising local and national activities. Many of the solidarity activities that took place in the main Irish and British cities, including Dublin, London and Glasgow, were announced widely via Twitter. Although communication about protests and activities organisation among solidarity group activists and their allies also took place through other lower profile communication methods such as emails and phone calls, Twitter was used to announce these activities, as well as to inform followers about how the events went.

The use of social media sites including Twitter for narrating in the activism context has been widely studied in light of the Arab Spring and Occupy Movement. Bennett and Segerberg (2012) have mentioned the personal stories of the Occupy Movement of 2011 that were widely spread through social media sites.

While Said (2004) explains that equality and justice are the motivators for solidarity activists around the globe, because 'it is a just cause, a noble ideal, a moral quest for equality and human rights'(2004, XVIII), Landy (2013) discussed the solidarity movement's human rights discourse, in which human rights has been seen as an 'acceptable language'. This discourse, as this paper finds, is still dominant in most online content. It does not only serve alliance building in the Irish and British context, but is also an aspect of the Palestinian struggle which can appeal to Western public opinion. 
However, highlighting the human rights aspects without considering the political context of the struggle could have implications for Irish and British perception of the conflict. That is to say, along with exposing the Israeli violations of the Palestinian people's human rights, it could be crucial to frame the conflict as a political struggle for independence and selfdetermination, in which resistance is a legitimate tool for the Palestinians to use to achieve their goal.

\section{References}

Aouragh, M. (2008) Palestine Online: Cyber Intifada and the Construction of a Virtual Community 2001-2005. PhD, University of Amsterdam.

Benford, R. D. and Snow, D. A. (2000). 'Framing Processes and Social Movements: An Overview and Assessment', Annual Review of Sociology, 26, 611-639.

Bennett, W. L. and Segerberg, A. (2012) 'The Logic Of Connective Action', Information, Communication and Society, 15, 739-768.

Castells, M. (2005) 'The Network Society: From Knowledge to Policy', in M. Castells and G. Cardoso (eds), The Network Society: From Knowledge to Policy, Washington, DC: Johns Hopkins Center for Transatlantic Relations.

Castells, M. (2012) Networks of Outrage and Hope : Social Movements in the Internet Age, Cambridge: Polity.

Cress, D. M. and Snow, D. A. (2000) 'The Outcomes of Homeless Mobilization: The Influence of Organization, Disruption, Political Mediation, and Framing', American Journal of Sociology, 105, 1063-1104.

Della Porta, D. and Diani, M. (1999) Social Movements: An Introduction, Oxford: Blackwell.

Diani, M. and McAdam, D. (eds), (2003) Social Movements and Networks Relational Approaches to Collective Action, Oxford: Oxford University Press.

Dudouet, V. (2006) 'Cross-border Non-violent Advocacy during the Second Palestinian Intifada: the Case of the International Solidarity Movement', in Xxx Unarmed Resistance: the Transnational Factor, Coventry University: Centre For Peace and Reconciliation Studies.

Holmes, D. (2005) Communication Theory: Media, Technology, Society, London: SAGE Publications Ltd.

Landy, D. (2013) 'Talking Human Rights: How Social Movement Activists are Constructed and Constrained by Human Rights Discourse', International Sociology, 28, 409-428.

Lee, J. (2009) 'Net Power in Action: Internet Activism in the Contentious Politics of South Korea', PhD, Rutgers: The State University of New Jersey.

Lipschutz, R. D. (2005) 'Networks of Knowledge and Practice: Global Civil Society and Global Communication', in W. Dejong, M. Shaw and N. Stammers (ed.), Global Activism, Global Media. London: Pluto Press.

Mabry, L. (2008) 'Case Study in Social Research', in P. Alasuutari, L. Bickman, and Brannen, J. (eds), The SAGE Handbook of Social Research Methods. London: SAGE Publications Ltd.

Marmura, S. M. E. (2008) Hegemony in the Digital Age : the Arab/lsraeli Conflict Online, Lanham, MD: Lexington Books. 
Melucci, A. (1995) 'The Process of Collective Identity', in H. Johnston and B. Klandermans (eds), Social Movements and Culture, Minneapolis: University of Minnesota Press.

Said, E. W. (2004) 'The Meaning of Rachel Corrie Of Dignity and Solidarity', in J. Sandercock, R. Sainath, M. McLaughlin, H. Khalili, N. Blincoe, H. Arraf and G. Andoni (eds), Peace Under Fire : Israel/Palestine and the International Solidarity Movement, London: Verso.

Seitz, C. (2003) 'ISM At the Crossroads: the Evolution of the International Solidarity Movement', Journal of Palestine Studies, 32, 50-67.

Shirky, C. (2008) Here Comes Everybody: The Power Of Organizing Without Organizations, New York: The Penguin Press.

Stamatopoulou-Robbins, S. C. (2005) 'Palestine Online : an Emerging Virtual Homeland?' RSC Working Paper 28. Oxford: Refugee Studies Centre, University of Oxford.

Tarrow, S. (1996) Power in Movement : Social Movements, Collective Action and Politics, Cambridge: Cambridge University Press.

Tarrow, S. (2011) Power in Movement: Social Movements and Contentious Politics, New York: Cambridge University Press.

Trottier, D. and Fuchs, C. (2015) Social Media, Politics and the State : Protests, Revolutions, Riots, Crime and Policing in the Age of Facebook, Twitter and YouTube, New York: Routledge.

Yin, R. K. (2003) Case Study Research Design and Methods, Thousand Oaks, Calif: Sage.

Shadi Abu-Ayyash, is a final year PhD student in digital arts. He is based at the Huston School of Film and Digital Media at the National University of Ireland Galway. A former journalist in Palestine, his research interests are Palestine solidarity movement, social movements, online activism, media framing theory, and media content analysis.

Email: shadi.abu-ayyash@ @uigalway.ie 